\title{
OPTIMASI PENGOLAHAN TEH KULIT BUAH NAGA (Hylocereus polyrhizus)
}

\section{OPTIMIZATION OF DRAGON FRUIT (Hylocereus polyrhizus) SKIN TEA PROCESSING}

\section{Mukhti Ali}

Program Studi Teknologi Pertanian, Fakultas Pertanian, Universitas Dehasen Bengkulu

\begin{abstract}
ABSTRAK
Kulit buah naga yang selama ini sebagai limbah belum diolah secara optimal, bahkan hanya dijadikan limbah oleh masyarakat, padahal kulit buah naga dapat diolah menjadi teh kulit buah naga. Tujuan penelitian ini adalah untuk mengetahui kadar antioksidan dan aktivitas antioksidan, serta tingkat kesukaan panelis terhadap teh kulit buah naga merah dan putih dengan metode pengeringan menggunakan oven, plastik UV, dan sinar matahari langsung. Penelitian ini juga bertujuan untuk menganalisis variasi jenis buah naga dan teknik pengeringan terhadap kadar antioksidan dan aktivitas antioksidan, serta sifat organoliptik teh kulit buah naga.

Pada penelitian ini digunakan enam kombinasi antara jenis buah naga (Merah dan Putih) dan metode pengeringan (Oven, Plastik UV, dan Sinar Matahari Langsung. Parameter yang dianalisis adalah kadar antioksidan dan aktivitas antioksidan dan tingkat kesukaan panelis terhadap warna, rasa, dan aroma.

Hasil penelitian menunjukkan bahwa terdapat pengaruh yang signifikan jenis buah naga terhadap kadar antioksidan dan aktivitas antioksidan pada taraf nyata 5\%. Sedangkan metode pengeringan tidak memberikan pengaruh yang berbeda terhadap kadar antioksidan dan aktivitas antioksidan. Berikutnya jenis buah naga juga memberikan pengaruh yang berbeda terhadap tingkat kesukaan panelis terhadap warna teh kulit buah naga, sedangkan metode pengeringan tidak memberikan pengaruh yang nyata. Namun, jenis buah naga tidak memberikan pengaruh yang nyata terhadap rasa dan aroma teh kulit buah naga. Begitu juga dengan metode pengeringan, tidak memberikan pengaruh yang nyata terhadap rasa dan aroma teh kulit buah naga.
\end{abstract}

Kata Kunci : kulit buah naga, proses pengeringan, teh, kadar antioksidan, aktivitas antioksidan.

\begin{abstract}
Dragon fruit skin that had not been processed as waste in an optimal, even just be a waste to society, but the skin can be processed into a dragon fruit dragon fruit peel tea. The purpose of this study was to determine the levels of antioxidants and antioxidant activity, as well as the preference level of the tea panelists red dragon fruit peel and white by using the oven drying method, UV plastic, and direct sunlight. The study also aimed to analyze variations in the type of dragon fruit and drying techniques to the levels of antioxidants and antioxidant activity, as well as the properties of tea organoliptik dragon fruit skin.

In this study used six combinations between types of dragon fruit (Red and White) and the drying method (Oven, Plastic UV and Direct Sunlight. The parameters analyzed were the levels of antioxidants and antioxidant activity and the level of A panelist on color, flavor, and aroma.
\end{abstract}


The results show that there is significant influence on the kind of dragon fruit antioxidant levels and antioxidant activity at the 5\% significance level. While the drying method does not give a different effect on the levels of antioxidants and antioxidant activity. The next type of dragon fruit also gives different effect on the preference level of the color of tea panelists dragon fruit skin, while the drying method does not provide a real impact. However, the type of dragon fruit no significant effect on the taste and aroma of tea dragon fruit skin. As well as the drying method, no significant effect on the taste and aroma of tea dragon fruit skin.

Keywords: dragon fruit skin, drying, tea, antioxidant levels, antioxidant activity.

\section{PENDAHULUAN}

Secara umum buah naga terdiri dari buah naga merah dan buah naga putih. Namun secara klasifikasi buah naga terdiri dari empat, yaitu buah naga daging putih (Hylocereus undatus), buahnaga daging merah (Hylocereus polyrhizus), buah naga daging super merah (Hylocereuscostaricensis), dan buah naga kulit kuning daging putih (Selenicerius megalanthus) (Emil, 2011). Dari keempat jenis buah naga tersebut memiliki kelebihan dan kekurangan masing-masing misalnya, buah naga merah terkenal dengan rasa manisnya, buah naga putih terkenal dengan ukurannya yang lebih besar (Kristianto, 200). Selama ini buah naga hanya dimanfaatkan daging buahnya saja, sedangkan kulitnya dibuang sebagai limbah karena dianggap tidak ada manfaatnya.

Limbah kulit buah naga merah masih sangat jarang dimanfaatkan. Padahal, kulit buah naga masih mengandung senyawa antioksidan yang cukup tinggi. Senyawa antioksidan mampu melawan oksidasi dalam tubuh. Pemanfaatannya yang dapat dilakukan pada kulit buah naga salah satunya adalah dengan mengekstraknya sehingga dapat dimanfaatkan sebagai bahan dasar beragam pangan fungsional yang akan bermanfaat bagi kesehatan. Namun pemanfaatan dengan cara mengekstraksi lebih sulit dilakukan karena banyak mengunakan peralatan dan pelaksanaannya membutuhkan ketelitian yang tinggi.

Pemanfaatan kulit buah naga merah yang paling mudah dilakukan adalah dengan cara diolah menjadi teh. Teh pada umumnya adalah serbuk yang berasal dari daun tumbuhan yang diolah dengan cara dikering. Kebayakan teh memang berasal dari tanaman teh tetapi ada juga daun yang diolah menjadi teh bukan berasal dari tanaman teh ( Camellia sinensis ) tetapi tanaman lain misalnya dari daun jambu biji. Pengolahan teh pada prinsipnya adalah mengeringkan bagian (lembaran) dari tanaman baik berupa daun maupun kulit dengan tujuan mengurangi kadar air pada bagian tersebut (Ghani, 
2002). Menurut Muchtadi dan Sugiono

(2013), teknik pengeringan yang dilakukan dapat berupa sun drying (dibawah sinar matahari), oven drying (mengunakan oven), dan teknik pengeringan yang lainnya. Beberapa teknik pengeringan mempunyai kelebihan dan kekurangan masing-masing sehingga perlunya penelitian teknik pengeringan yang tepat.

\section{METODOLOGI PENELITIAN}

\section{Bahan dan Alat}

Bahan yang digunakan dalam penelitian ini adalah kulit buah naga merah dan putih, dan air.

Alat yang digunakan dalam penelitian ini adalah baskom untuk wadah kulit buah naga.pisau digunakan untuk mengiris /membelah kulit buah naga, talenan digunakan untuk alas sewaktu mengiris kulit buah naga, timbangan untuk mengukur bahan-bahan yang diperlukan.oven, rak pengering dengan plastik UV, tampah dan alat analisis kimia

\section{Metode}

1. Proses pengolahan teh kulit buah naga Kulit buah naga merah atau putih diiris-iris menjadi potongan kecil-kecil 0,5 cm kemudian dilakukan pengeringan, dengan variasi perlakuan : menggunakan oven drying, rak pengering menggunakan plastik UV, dan dengan penjemuran langsung dibawah sinar matahari.

2. Pengeringan dilakukan sebagai berikut dengan menggunakan :

a. Oven; suhu $38^{\circ} \mathrm{C}$, waktu8 Jam.

b. Rak pengering dengan plastik UV; suhu $30-35^{\circ} \mathrm{C}$, waktu 20 jam dan

c. sinar matahari; suhu $30-35^{\circ} \mathrm{C}$ waktu24 jam.

3. Analisis kimia (kandungan anti oksidan) dan uji organoleptik.

\section{HASIL DAN PEMBAHASAN}

Kadar Antioksidan Teh Kulit Buah Naga

Pada penelitian ini digunakan enam buah sampel kulit buah naga, yakni kulit buah naga merah oven, kulit buah naga merah yang dikeringkan di bawah sinar matahari namun diberi pelindung plastik UV, kulit buah naga merah di bawah sinar matahari langsung, kulit buah naga putih oven, kulit buah naga putih yang dikeringkan di bawah sinar matahari namun diberi pelindung plastik UV, kulit buah naga putih di bawah sinar matahari langsung.

Parameter yang di analisis pada penelitian ini adalah kadar antioksidan dan aktivitas antioksidan. Gambaran hasil uji laboratorium kadar antioksidan pada keenam sampel teh kulit buah naga dapat dilihat pada tabel 1 . 
Tabel 1. Kadar Antioksidan Teh Kulit Buah Naga Terhadap Variasi Jenis Buah Naga dan Metode Pengeringan

\begin{tabular}{lcrc}
\hline Jenis Buah Naga & \multicolumn{3}{c}{ Metode Pengeringan } \\
\cline { 2 - 4 } & \multicolumn{1}{l}{ Oven } & Plastik UV & Matahari Langsung \\
\hline Merah & $20,42 \% \mathrm{a}$ & $20,12 \% \mathrm{a}$ & $20,04 \% \mathrm{a}$ \\
Putih & $11,65 \% \mathrm{~b}$ & $11,27 \% \mathrm{~b}$ & $11,07 \% \mathrm{~b}$
\end{tabular}

Ket : Angka yang diikuti oleh kode huruf yang berbeda menunjukkan adanya perbedaan nyata pada taraf signifikansi $5 \%$

Pada uji pengaruh jenis kulit buah naga terhadap kadar antioksidan diperoleh bahwa nilai $p$-value $=0,001<0,05$, sehingga hipotesis nol ditolak, artinya warna kulit buah naga memberikan pengaruh yang berbeda terhadap kadar antioksidan teh kulit buah naga. Sedangkan pada uji pengaruh metode pengeringan terhadap kadar antioksidan pada teh kulit buah naga diperoleh nilai $p$-value $=0,256>0,05$ sehingga hipotesis nol diterima, artinya tidak terdapat pengaruh yang berbeda metode pengeringan terhadap kadar antioksidan teh kulit buah naga.
Pada tabel 1 dapat dilihat bahwa teh kulit buah naga yang berwarna merah memiliki kadar antioksidan yang lebih tinggi dibandingkan dengan teh kulit buah naga berwarna putih. Menurut Wisesa (2014) kadar antioksidan buah naga tergantung dengan kandungan antioksidannya.

Pada tabel 2 menunjukkan buah naga merah memiliki kandungan zat antioksidan yang lebih tinggi dibandingkan dengan buah naga putih. Oleh karena itu terdapat perbedaan pengaruh jenis buah naga kadar antioksidan buah naga merah dan putih terhadap kadar antioksidan.

\section{Tabel 2.Kandungan Zat Antioksidan Buah Naga}

\begin{tabular}{lllll}
\hline Jenis Buah Naga & TSP $(\mu \mathrm{g} \mathrm{GA} / \mathrm{g}$ & $\begin{array}{l}\text { TAA }(\mathrm{mg} / 100 \mathrm{~g} \\
\text { puree })\end{array}$ & $\begin{array}{l}\text { ORAC } \\
\text { TE/g puree })\end{array}$ & $\begin{array}{l}\text { DPPH } \\
\text { GA/g puree })\end{array}$ \\
\hline Merah & $1075.8 \pm 71.7$ & $55.8 \pm 2.0$ & $7.6 \pm 0.1$ & $134.1 \pm 30.1$ \\
Putih & $523.4 \pm 33.6$ & $13.0 \pm 1.5$ & $3.0 \pm 0.2$ & $34.7 \pm 7.3$ \\
\hline
\end{tabular}

Sumber : Mahattanatawee et al, 2006

Keterangan :TSP : Total Soluble Phenolic, TAA : Total Ascorbic Acid, ORAC : Oxygen Radical Absorbance Capacity 
Kadar antioksidan teh kulit buah naga tertinggi adalah pada teh kulit buah naga berwarna merah dengan metode pengeringan menggunakan oven, yakni sebesar 20,42\%. Sedangkan kadar antioksidan terendah adalah pada teh kulit buah naga berwarna putih dengan metode pengeringan dibawah matahari langsung, yakni $11,07 \%$.

\section{Aktivitas Antioksidan Teh Kulit Buah Naga}

Gambaran hasil uji laboratorium aktivitas antioksidan pada keenam sampel kulit buah naga dapat dilihat pada tabel 3 .

Pada uji pengaruh jenis kulit buah naga terhadap aktivitas antioksidan diperoleh bahwa nilai $p$-value $=0,002<0,05$, sehingga hipotesis nol ditolak, artinya warna kulit buah naga memberikan pengaruh yang berbeda terhadap aktivitas antioksidan teh kulit buah naga. Hal ini tentunya disebabkan oleh kandungan zat antioksidan yang berbeda antara buah naga merah dan putih. dengan kandungan zat antioksidan Sedangkan pada uji pengaruh metode pengeringan terhadap aktivitas antioksidan pada teh kulit buah naga diperoleh nilai $p-$ value $=0,161>$ 0,05 sehingga hipotesis nol diterima, artinya tidak terdapat pengaruh yang berbeda metode pengeringan terhadap aktivitas antioksidan teh kulit buah naga.

Pada tabel 3 dapat dilihat bahwa teh kulit buah naga yang berwarna merah memiliki aktivitas antioksidan yang lebih tinggi dibandingkan dengan teh kulit buah naga berwarna putih. Kadar antioksidan teh kulit buah naga tertinggi adalah pada teh kulit buah naga berwarna merah dengan metode pengeringan menggunakan oven, yakni sebesar 7,44/mol. Sedangkan kadar antioksidan terendah adalah pada teh kulit buah naga berwarna putih dengan metode pengeringan dibawah matahari langsung, 2,11/mol.

Tabel 3. Aktivitas Antioksidan Teh Kulit Buah Naga Terhadap Variasi Jenis Buah Naga dan Metode Pengeringan

\begin{tabular}{llcc}
\hline Jenis Buah Naga & \multicolumn{3}{c}{ Metode Pengeringan } \\
\cline { 2 - 4 } & Oven & Plastik UV & Matahari Langsung \\
\hline Merah & $7,44 / \mathrm{mol} \mathrm{a}$ & $7,29 / \mathrm{mol} \mathrm{a}$ & $7,14 / \mathrm{mol} \mathrm{a}$ \\
Putih & $2,65 / \mathrm{mol} \mathrm{b}$ & $2,31 / \mathrm{mol} \mathrm{b}$ & $2,11 / \mathrm{mol} \mathrm{b}$
\end{tabular}

Ket : Angka yang diikuti oleh kode huruf yang berbeda menunjukkan adanya perbedaan nyata pada taraf signifikansi 5\% 
Sifat Sensoris Warna Teh Kulit Buah Naga

Pada penelitian ini, terdapat 2 warna teh kulit buah naga yang diberikan, yakni merah dan putih. Dilakukan uji kesukaan (hedonik) responden yang berjumlah 20 orang terhadap warna teh kulit buah naga. Nilai rata-rata kesukaan panelis terhadap warna teh kulit buah naga disajikan pada tabel 4 .

Pada uji beda tingkat kesukaan responden terhadap warna pada jenis teh kulit buah naga dengan variasi metode pengeringan dan warna kulit buah naga diperoleh bahwa terdapat perbedaan tingkat kesukaan responden terhadap warna pada variasi warna kulit buah naga. Hal ini didasarkan pada nilai $p$-value $=0,002$ $<0,05$, sehingga hipotesis nol ditolak, artinya warna kulit buah naga memberikan pengaruh yang berbeda terhadap tingkat kesukaan responden terhadap warna teh kulit buah naga. Berikutnya metode pengeringan teh kulit buah naga tidak memberikan pengaruh yang berbeda pada tingkat kesukaan responden terhadap warna teh kulit buah naga, karena nilai $p$-value $=0,136>$ 0,05 sehingga hipotesis nol diterima, artinya tidak terdapat pengaruh yang berbeda metode pengeringan terhadap tingkat kesukaan warna teh kulit buah naga. Akan tetapi, interaksi antara warna kulit buah naga dan metode pengeringan memberikan pengaruh yang berbeda pada tingkat kesukaan terhadap warna teh kulit buah naga. Hal ini dapat dilihat dari nilai $p$-value $=0,045<0,5$, hipotesis nol ditolak, artinya terdapat perbedaan pengaruh interaksi warna kulit buah naga dan metode pengeringan terhadap tingkat kesukaan terhadap warna.

Pada tabel 4 dapat dilihat bahwa tingkat kesukaan tertinggi responden terhadap warna teh kulit buah naga adalah pada teh kulit buah naga yang berasal dari kulit buah naga berwarna merah dan metode pengeringan menggunakan plastik UV. Rata-rata kesukaan responden terhadap warna teh kulit buah naga ini adalah $3,85 \approx 4$ yang berarti responden suka terhadap teh kulit buah naga tipe ini. Salah satu alasan yang mungkin adalah berdasarkan pengamatan warna teh kulit buah naga merah yang dikeringkan dengan bantuan plastik UV memiliki kualitas warna yang lebih terang dibandingkan dengan teh jenis lain. Seduhan teh kulit buah naga yang berasal dari kulit buah naga merah dan dikeringkan langsung di bawah sinar matahari juga memiliki tingkat kesukaan yang cukup tinggi, yakni 3,75. Hal ini berarti respon suka terhadap teh jenis ini. Sedangkan tingkat kesukaan responden terhadap teh kulit naga tipe lainnya, berada pada kategori agak suka. Hal ini dapat dilihat dari rata-rata tingkat 
kesukaan responden yang lebih besar dari 3.

\section{Sifat Sensoris Rasa Teh Kulit Buah Naga}

Pada penelitian ini, terdapat 2 warna teh kulit buah naga yang diberikan, yakni Merah dan Putih. Dilakukan uji kesukaan (hedonik) responden yang berjumlah 20 orang terhadap rasa teh kulit buah naga. Nilai rata-rata kesukaan panelis terhadap rasa teh kulit buah naga disajikan pada tabel 5.

Pada tabel 5 dapat dilihat bahwa tingkat kesukaan tertinggi responden terhadap rasa teh kulit buah naga adalah pada teh kulit buah naga yang berasal dari kulit buah naga berwarna merah dan metode pengeringan menggunakan matahari langsung. Rata-rata kesukaan responden terhadap rasa teh kulit buah naga ini adalah $3,30 \approx 3$ yang berarti responden lumayan suka terhadap teh kulit buah naga tipe ini. Teh kulit buah naga yang berasal dari kulit buah naga merah dan dikeringkan dengan metode plastik UV juga memiliki tingkat kesukaan rasa yang hampir sama dengan tipe teh kulit buah naga dari kulit buah naga merah dan dikeringkan dengan plastik UV, rata-rata tingkat kesukaan rasa sebesar 3,20. Hal ini berarti respon agak suka terhadap teh jenis ini.
Pada uji beda tingkat kesukaan responden terhadap rasa pada jenis teh kulit buah naga dengan variasi jenis buah naga dan metode pengeringan diperoleh bahwa tidak terdapat perbedaan tingkat kesukaan responden terhadap rasa pada variasi warna kulit buah naga. Hal ini didasarkan pada nilai $p$-value $=0,264>0,05$, sehingga hipotesis nol diterima, artinya warna kulit buah naga memberikan pengaruh yang berbeda terhadap tingkat kesukaan responden terhadap rasa teh kulit buah naga. Berikutnya juga metode pengeringan teh kulit buah naga tidak memberikan pengaruh yang berbeda pada tingkat kesukaan responden terhadap rasa teh kulit buah naga, karena nilai $p-$ value $=0,271>0,05$ sehingga hipotesis nol diterima, artinya tidak terdapat pengaruh yang berbeda metode pengeringan terhadap tingkat kesukaan rasa teh kulit buah naga. Begitu juga interaksi antara warna kulit buah naga dan metode pengeringan tidak memberikan pengaruh yang berbeda pada tingkat kesukaan terhadap rasa teh kulit buah naga. Hal ini dapat dilihat dari nilai $p-$ value $=0,821>0,05$, hipotesis nol diterima, artinya tidak terdapat perbedaan pengaruh interaksi warna kulit buah naga dan metode pengeringan terhadap tingkat kesukaan rasa teh kulit buah naga. 
Tabel 4. Analisis Hedonik Warna Teh Kulit Buah Naga Variasi Jenis Buah Naga dan Metode Pengeringan

\begin{tabular}{lccc}
\hline Jenis Buah Naga & \multicolumn{3}{c}{ Metode Pengeringan } \\
\cline { 2 - 4 } & Oven & Plastik UV & Matahari Langsung \\
\hline Merah & $3,10 \mathrm{a}$ & $3,85 \mathrm{a}$ & $3,75 \mathrm{a}$ \\
Putih & $3,15 \mathrm{~b}$ & $3,05 \mathrm{~b}$ & $3,10 \mathrm{~b}$
\end{tabular}

Ket : Angka yang diikuti oleh kode huruf yang berbeda menunjukkan adanya perbedaan nyata pada taraf signifikansi 5\%. Skala : $1=$ Sangat Tidak Suka, $2=$ tidak Suka, $3=$ Agak Suka, $4=$ Suka, 5 = Sangat Suka.

Tabel 5. Analisis Hedonik Rasa Teh Kulit Buah Naga Variasi Jenis Buah Naga dan Metode Pengeringan

\begin{tabular}{lccc}
\hline Jenis Kulit Buah Naga & \multicolumn{3}{c}{ Metode Pengeringan } \\
\cline { 2 - 4 } & \multicolumn{1}{c}{ Oven } & Plastik UV & Matahari Langsung \\
\hline Merah & $2,90 \mathrm{a}$ & $3,20 \mathrm{a}$ & $3,30 \mathrm{a}$ \\
Putih & $2,85 \mathrm{a}$ & $2,90 \mathrm{a}$ & $3,10 \mathrm{a}$
\end{tabular}

Ket : Angka yang diikuti oleh kode huruf yang berbeda menunjukkan adanya perbedaan nyata pada taraf signifikansi 5\%. Skala : $1=$ Sangat Tidak Suka, $2=$ tidak Suka, $3=$ Agak Suka, $4=$ Suka, 5 = Sangat Suka.

Sifat Sensoris Aroma Teh Kulit Buah Naga

Dilakukan uji kesukaan (hedonik) responden yang berjumlah 20 orang terhadap aroma teh kulit buah naga. Nilai rata-rata kesukaan panelis terhadap aroma teh kulit buah naga disajikan pada tabel 6 .

Pada tabel 6 dapat dilihat bahwa tingkat kesukaan tertinggi responden terhadap aroma teh kulit buah naga adalah pada teh kulit buah naga yang berasal dari kulit buah naga berwarna merah dan metode pengeringan menggunakan matahari langsung dan teh kulit buah naga dari kulit buah naga merah dan metode pengeringan dengan plastik UV. Rata-rata kesukaan responden terhadap rasa teh kulit buah naga ini adalah $3,20 \approx 3$ yang berarti responden lumayan suka terhadap aroma teh kulit buah naga kedua tipe ini.

Pada uji beda tingkat kesukaan responden terhadap aroma pada jenis teh kulit buah naga dengan variasi metode pengeringan dan warna kulit buah naga diperoleh bahwa tidak terdapat perbedaan tingkat kesukaan responden terhadap aroma pada variasi warna kulit buah naga. Hal ini didasarkan pada nilai $p$-value $=0,478$ $>0,05$, sehingga hipotesis nol diterima, artinya warna kulit buah naga memberikan pengaruh yang berbeda terhadap tingkat kesukaan responden terhadap aroma teh kulit buah naga. 
Tabel 6. Analisis Hedonik Aroma Teh Kulit Buah Naga Variasi Jenis Buah Naga dan Metode Pengeringan

\begin{tabular}{lccc}
\hline Jenis Buah Naga & \multicolumn{3}{c}{ Metode Pengeringan } \\
\cline { 2 - 4 } & Oven & Plastik UV & Matahari Langsung \\
\hline Merah & $3,10 \mathrm{a}$ & $3,20 \mathrm{a}$ & $3,20 \mathrm{a}$ \\
Putih & $2,95 \mathrm{a}$ & $3,10 \mathrm{a}$ & $3,15 \mathrm{a}$
\end{tabular}

Ket : Angka yang diikuti oleh kode huruf yang berbeda menunjukkan adanya perbedaan nyata pada taraf signifikansi 5\%. Skala : $1=$ Sangat Tidak Suka, $2=$ tidak Suka, $3=$ Agak Suka, $4=$ Suka, 5 = Sangat Suka.

Metode pengeringan teh kulit buah naga tidak memberikan pengaruh yang berbeda pada tingkat kesukaan responden terhadap aroma teh kulit buah naga, karena nilai $p$-value $=0,648>0,05$ sehingga hipotesis nol diterima, artinya tidak terdapat pengaruh yang berbeda metode pengeringan terhadap tingkat kesukaan aroma teh kulit buah naga. Begitu juga interaksi antara warna kulit buah naga dan metode pengeringan tidak memberikan pengaruh yang berbeda pada tingkat kesukaan terhadap aroma teh kulit buah naga. Hal ini dapat dilihat dari nilai $p-$ value $=0,951>0,05$, hipotesis nol diterima, artinya tidak terdapat perbedaan pengaruh interaksi warna kulit buah naga dan metode pengeringan terhadap tingkat kesukaan aroma teh kulit buah naga.

\section{SIMPULAN}

Jenis buah naga memberikan pengaruh yang berbeda terhadap kadar antioksidan dan aktivitas antioksidan. Sedangkan metode pengeringan tidak memberikan pengaruh yang berbeda pada kadar antioksidan dengn nilai $(11,07 \%$ s.d 20,42\%) dan aktivitas antioksidan dengan nilai $(2,11 / \mathrm{mol}$ s.d $7,44 / \mathrm{mol})$. Sementara metode pengeringan tidak memberikan pengaruh yang nyata terhadap kadar antioksidan dan aktivitas antioksidan.

Jenis buah naga memberikan pengaruh yang nyata terhadap tingkat kesukaan panelis terhadap warna teh kulit buah naga, tetapi tidak memberikan pengaruh yang nyata terhadap rasa dan aroma teh kulit buah naga. Sementara metode pengeringan tidak memberikan panguruh yang nyata terhadap warna, rasa, dan aroma teh kulit buah naga.

\section{DAFTAR PUSTAKA}

Amanda, Rianti. 2008. Khasiat Tanaman Herbal untuk Tubuh. Pringganidani : Padalarang.

Emil S. 2011. Untung Berlipat Dari Bisnis Buah Naga Unggul. Lily Publisher. Yogyakarta.

Ghani, Mohamad A. 2002. Dasar-dasar Budidaya Teh. Penebar Swadaya. Jakarta

Kristianto, Daniel. 2003. Buah Naga. Penebar Swadaya. Surabaya 
Muchtadi dan Sugiyono.2013.Prinsip Proses \& Teknologi Pangan.Alfabeta. Bandung

Setyamidjaja, Djoehana. 1998. Teh Budidaya dan Pengolahan Pasca Panen. Kanisius. Yogyakarta.

Tarbiana, F.2013. Analisis Kualitas Produk Surabi Berbasis Organoleptik Pada Pedagang
Surabi di Kota Bandung.UPI. Bandung

Usman, H. 2006. Pengantar Statistik. Bumi Aksara. Yogyakarta

Wisesa. 2014. Penentuan Nilai Maksimum Proses Ekstraksi Kulit Buah Naga Merah. Jurnal Pangan dan Agroindustri Vol.2 No.3 p.88-97, Juli 2014 